\title{
The Efficacy of Linezolid in the Treatment of Pulmonary Tuberculosis Combined with Severe Pneumonia and Its Effect on the Prognosis
}

\author{
YI LIU AND XIANGRONG ZHANG*
}

Department of Tuberculosis, The Second Hospital of Nanjing, Nanjing University of Chinese Medicine, Nanjing, Jiangsu 210003, China

\begin{abstract}
Liu et al.: Linezolid Effect in the Treatment of Pulmonary Tuberculosis Combined with Severe Pneumonia To investigate the efficacy of linezolid in the treatment of pulmonary tuberculosis combined with severe pneumonia and its effect on the prognosis. 72 patients with pulmonary tuberculosis combined with severe pneumonia were selected in our hospital and random divided into control and observation group. Patients in both groups first received basic symptomatic treatment. On this basis, the control group was given isoniazid injection intravenously while the observation group was given linezolid glucose injection intravenously as an adjunctive treatment and both groups were treated continuously for $14 \mathrm{~d}$. The clinical efficacy, bacterial clearance rate, immune function, cytokine levels and incidence of adverse reactions were compared between the two groups after $28 \mathrm{~d}$ treatment. The results showed that the total effective and bacterial clearance rate in the observation group were higher than those in the group $(p<0.05)$ and the levels of cluster of differentiation 4, cluster of differentiation 8, cluster of differentiation 4/cluster of differentiation 8, immunoglobulin a and immunoglobulin g were increased while the levels of interleukin-6, interleukin-8 and tumour necrosis factor alpha were decreased in two groups after treatment $(p<0.05)$ and the observation group was significantly different than that of the control group $(\mathbf{p}<0.05)$. The use of linezolid in the treatment of patients with tuberculosis combined with severe pneumonia is clinically effective and safe and is worthy of clinical application.
\end{abstract}

Key words: Tuberculosis, pneumonia, linezolid, inflammatory factor, immune function

Tuberculosis is a common chronic infectious disease and its transmission mode is mainly respiratory transmission. Patients with tuberculosis will have a rapid decline in immunity, commonly accompanied by infection of other bacteria in the lower respiratory tract. With the continuous spread of infection, severe pneumonia may occur, endangering patients' life safety ${ }^{[1]}$. As antimicrobial agents, isoniazid and rifampicin are commonly used in the current clinical treatment of this disease. However, with the increase in the use of antimicrobial agents in recent years, the resistance to Staphylococcus aureus and other antimicrobial agents has gradually become stronger, which further increases the difficulty in the treatment of lung diseases and leads to poor efficacy by medication alone $^{[2]}$.
Linezolid is a synthetic antibiotic of oxazolidinones, which can be used in the treatment by aerobic infections caused by gram positive bacteria, in clinical treatment for this kind of bacterium infection has shown advantage ${ }^{[3]}$, including methicillin resistant Staphylococcus aureus, vancomycin resistant Enterococcus and penicillin and (or) large ring lactone class resistant pneumococci, etc. Linezolid has also been reported to be effective in the treatment of Mycobacterium avium infection and multidrug-resistant tuberculosis ${ }^{[4]}$. In this study, 72 patients with pulmonary tuberculosis complicated with severe pneumonia were studied, aiming to explore the clinical treatment effect of linezolid in patients with pulmonary tuberculosis complicated with severe pneumonia.

*Address for correspondence

E-mail: fsyy01721@njucm.edu.cn 


\section{MATERIALS AND METHODS}

\section{General information:}

A total of 72 patients with tuberculosis complicated with severe pneumonia were admitted to the Tuberculosis Department of Nanjing Second Hospital from October 2019 to October 2020. All patients with body weight $\geq 50 \mathrm{~kg}$, were selected and divided into control group and observation group according to random drawing, with 36 patients in each group. The control group had 19 males and 17 females. Their age ranged from 18 to $70 \mathrm{y}$, with an average of $(41.46 \pm 1.25) \mathrm{y}$. The course of disease ranged from 1 to $8 \mathrm{y}$, with an average of $(4.28 \pm 1.10)$ y. The observation group included 20 males and 16 females. The average age was $(42.20 \pm 2.11)$ y from 20 to $75 \mathrm{y}$ old. The course of disease ranged from 1 to $10 \mathrm{y}$, with an average of $(4.43 \pm 1.22) \mathrm{y}$.

Inclusion criteria: All patients met the criteria of pulmonary tuberculosis complicated with severe pneumonia after diagnosis of imaging examination, laboratory observation and clinical manifestations; Good treatment compliance; Age $>18$ y old.

Exclusion criteria: Water electrolyte, acid-base balance is seriously disturbed; Severe impairment of liver and kidney function; drug allergy. This study was approved by the hospital ethics committee with informed consent of the patients and their families. There was no significant difference in gender, age and other general data between the two groups $(p>0.05)$, indicating comparability.

\section{Therapeutic method:}

Patients in both groups received basic symptomatic treatment, such as expectoration, nutritional support, oxygen inhalation, antipyretic treatment and fluid replacement, to ensure the airway patency. On this basis, control group was given intravenous infusion of isoniazid injection, $300 \mathrm{mg} / \mathrm{time}$, once/d; Rifampicin injection intravenously, $0.6 \mathrm{~g} / \mathrm{time}$, once/d; Ethambutol hydrochloride tablets for oral treatment, $0.75 \mathrm{~g} /$ time, once/d; Pyrazinamide tablets for oral treatment, 0.5 $\mathrm{g} /$ time, 3 Times/d. On the basis of the control group, patients in the study group received adjuvant therapy of linezolid glucose injection intravenously, $600 \mathrm{mg} /$ time, once every $12 \mathrm{~h}$, twice/d. Both groups were treated continuously for $14 \mathrm{~d}$.

\section{Observation indexes and efficacy evaluation:}

Clinical efficacy, bacterial culture results, bacterial clearance rate and immune function of 2 groups were observed after 4 w of treatment(Cluster of Differentiation
$4\left(\mathrm{CD}^{+}\right), \mathrm{CD}^{+}, \mathrm{CD}^{+} / \mathrm{CD}^{+}$, Immunoglobulin $\mathrm{A}(\operatorname{Ig} \mathrm{A})$ and IgG), cytokines (Interleukin-6 (IL-6), IL-8 and Tumour Necrosis Factor Alpha (TNF- $\alpha)$ ) and adverse events.

Detection of bacterial clearance rate: Before treatment and at the end of treatment, the sputum of the patients was taken for bacterial culture. The sputum was taken once every $12 \mathrm{~h}$ for continuous culture for $3 \mathrm{~d}$ and the same pathogen was found in 3 cultures, indicating positive bacterial culture. Biofosun automatic bacterial identification instrument (Shanghai Jingrui Scientific Instrument Co., Ltd.) was used for identification.

Immune function test: Before treatment and $4 \mathrm{w}$ after treatment, 2 test tubes of $5 \mathrm{ml}$ venous blood were extracted from 2 groups of patients and Dipotassium Ethylenediaminetetraacetic Acid (EDTA-K2) anticoagulant was used to reverse and mix timely. $\mathrm{CD}^{+}$and $\mathrm{CD} 8^{+}$levels were detected by flow cytometry (Minray, BricyteE6) and cell counting meter(Guangzhou Vijay Technology Co., Ltd., JSY-SC-021H). IgA and IgG were detected by immunoturbidimetry. All the kits were purchased from Zhejiang Aikang Biotechnology Co., Ltd.

Cytokine detection: $5 \mathrm{ml}$ of venous blood was extracted from 2 groups and the upper serum was collected by low-speed centrifugation. The levels of IL-6, IL- 8 and TNF- $\alpha$ were determined by EnzymeLinked Immunosorbent Assay (ELISA). The ELISA kit was purchased from Beijing Yiqiao Shenzhou Biotechnology Co., Ltd.

\section{Evaluation of therapeutic efficiency:}

Clinical curative effect: According to the Guiding Principles for Clinical Application of Antimicrobial Agents, the evaluation can be divided into cured, obvious effective, effective and ineffective $\mathrm{e}^{[5]}$.

Recovery: The body temperature returned to normal, the imaging examination and laboratory examination results were normal, the infected bacteria were completely cleared and the mental state was good.

Significant effect: The body temperature was basically normal, the results of laboratory examination and imaging examination were significantly improved, the infected bacteria were partially cleared and the mental state was basically restored.

Effective: The body temperature decreased, the symptoms and examination results were not significantly improved and the mental state was not significantly improved. 
No effect: No improvement or even deterioration $72 \mathrm{~h}$ after treatment. Total effective rate $=($ cured + effective $) /$ total number of cases $\times 100 \%$.

Bacterial Clearance Rate-According to the standards established by the National Committee for Clinical Laboratory Standards (NCCLS) (2002), the evaluation was divided into clearance, hypothetical clearance, replacement, unclearance and reinfection ${ }^{[6]}$.

Clearance: No pathogen was found in sputum samples collected $24 \mathrm{~h}$ after treatment.

Hypothesis clearance: After treatment, the patient had a significant clinical effect, but no good culture specimens were obtained and the bacterial culture of the samples before treatment was positive. Replacementculture without the original pathogenic bacteria, but find new pathogens that do not need treatment.

Not cleared: The original pathogenic bacteria were still positive after treatment.

Reinfection: Culture does not find the original pathogen, but finds a new pathogen that needs treatment. Total clearance rate $=($ clearance + hypothetical clearance + replacement)/total number of cases $\times 100 \%$.

\section{Follow up methods:}

Follow up was $28 \mathrm{~d}$ after treatment and the end point was all-cause death.

\section{Statistical analysis:}

Statistical Package for the Social Sciences (SPSS) 22.0 statistical software was used for data analysis. Measurement data were expressed as mean \pm standard deviation $(\mathrm{x} \pm \mathrm{s})$ and t-test was used for comparison. Enumeration data were expressed as rate $(\%)$ and $\chi^{2}$ test was used for comparison. $\mathrm{p}<0.05$ was considered statistically significant.

\section{RESULTS AND DISCUSSION}

The total effective rate of the observation group was significantly higher than that of the control group, and the difference between the two groups was statistically significant $(\mathrm{p}<0.05)$, as shown in Table 1 .

In the two groups, 34 cases of methicillin-resistant Staphylococcus aureus (47.22 \%), 33 cases of Pseudomonas aeruginosa (45.83 \%), 25 cases of Klebsiella pneumoniae (34.72\%), 23 cases of Acinetobacter baumannii (31.94 \%) and 9 cases of Enterococcus faecalis (12. $50 \%$ ), 10 cases of Stenotrophomonas maltophilia (13.89\%), 4 cases of
Staphylococcus haemolyticus $(5.56 \%)$ and 40 cases of mixed infection (55.56\%). The bacterial clearance rate of the observation group was significantly higher than that of the control group ( $<<0.05)$, as shown in Table 2 .

Before treatment, there were no significant differences in the levels of $\mathrm{CD}^{+}, \mathrm{CD}^{+}, \mathrm{CD}^{+} / \mathrm{CD}^{+}, \mathrm{IgA}$ and $\mathrm{IgG}$ between 2 groups (all $\mathrm{p}>0.05$ ). After $4 \mathrm{w}$ of treatment, the above indexes in 2 groups were significantly higher than before treatment $($ all $p<0.05)$ and the above indexes in the observation group were higher than those in the control group (all $\mathrm{p}<0.05$ ), as shown in Table 3 .

Before treatment, there were no significant differences in the levels of IL-6, IL-8 and TNF- $\alpha$ between 2 groups $(p<0.05)$. After treatment, the above indexes in 2 groups were significantly lower than before treatment $($ all $\mathrm{p}<0.05)$ and the above indexes in the observation group were significantly lower than those in the control group (all $\mathrm{p}<0.001$ ), as shown in Table 4 .

After treatment, there was no statistical significance in the incidence of Adverse Drug Reactions (ADR) between 2 groups ( $p>0.05)$, as shown in Table 5 .

In recent years, due to the widespread use of broad spectrum antimicrobial drugs, the incidence of Multidrug-Resistant Tuberculosis (MDR-TB) has been increasing year by year. Besides, pulmonary structural changes have been found in tuberculosis patients and mixed infection is common. In this study, 40 cases were mixed infection, accounting for $55.56 \%$, which further increased the difficulty of tuberculosis treatment. Severe pneumonia is a common complication of tuberculosis patients and MethicillinResistant Staphylococcus aureus (MRSA) is one of the main pathogens causing severe pneumonia. Therefore, it is particularly important to find an antibiotic to treat multi-drug resistance in patients with tuberculosis complicated with severe pneumonia.

Linezolid is a synthetic broad spectrum of new antimicrobial agent against gram positive coccus. The principle is that, in the initial stage of the bacterial protein translation by inhibiting bacterial protein synthesis to antibacterial effect ${ }^{[6]}$, does not affect the peptidyl transferase activity, therefore, it is not easy to rina thiazole amine with other inhibit protein synthesis of cross resistance to antimicrobial agents, can be used to MRSA and other gram-positive bacteria resistant treatment ${ }^{[7,8]}$. Moreover, it has been reported that the cure rate of linezolid combined with other drugs for MDR-TB is $69 \% \sim 92 \%$. 
TABLE 1: COMPARISON OF CLINICAL EFFICACY BETWEEN THE TWO GROUPS OF PATIENTS WITH TUBERCULOSIS COMPLICATED WITH SEVERE PNEUMONIA

\begin{tabular}{lcccccc}
\hline Group & $\mathrm{n}$ & Cure & Obvious effect & Effective & Ineffective & Total effective \\
\hline $\begin{array}{l}\text { Observation } \\
\text { group }\end{array}$ & 36 & $7(19.44)$ & $11(30.56)$ & $14(38.89)$ & $4(11.11)$ & $32(88.89)$ \\
Control group & 36 & $5(13.89)$ & $9(25.00)$ & $12(33.33)$ & $10(27.78)$ & $26(72.22)$ \\
\hline
\end{tabular}

Note: Comparison of total effective rate between the two groups, $x^{2}=4.356 ; p=0.037$

TABLE 2: COMPARISON OF BACTERIAL CLEARANCE RATE IN PATIENTS WITH PULMONARY TUBERCULOSIS COMPLICATED WITH SEVERE PNEUMONIA

\begin{tabular}{lccccccc}
\hline Group & $\mathrm{n}$ & Clearance & $\begin{array}{c}\text { Hypothetical } \\
\text { clearance }\end{array}$ & Replacement & Unclearance & Reinfection & $\begin{array}{c}\text { Total } \\
\text { clearance }\end{array}$ \\
\hline $\begin{array}{l}\text { Observation } \\
\text { group }\end{array}$ & 36 & $9(25.00)$ & $12(33.33)$ & $8(22.22)$ & $5(13.89)$ & $2(5.56)$ & $29(80.55)$ \\
Control group & 36 & $5(13.89)$ & $10(27.78)$ & $5(13.89)$ & $10(27.89)$ & $6(16.33)$ & $20(55.56)$ \\
\hline
\end{tabular}

Note: Comparison of total clearance rate between the two groups, $x^{2}=5.709 ; p=0.017$

TABLE 3: IMMUNE INDEXES BEFORE AND AFTER TREATMENT IN THE TWO GROUPS

\begin{tabular}{|c|c|c|c|c|c|c|c|c|c|c|c|}
\hline \multirow[b]{2}{*}{ Group } & & \multirow{2}{*}{\multicolumn{2}{|c|}{$\mathrm{n}$}} & \multicolumn{2}{|c|}{$\mathrm{CD4}^{+}(\%)$} & \multicolumn{2}{|c|}{$\mathrm{CD}^{+} / \mathrm{CD}^{+}$} & \multicolumn{2}{|c|}{$\lg A(g / l)$} & \multicolumn{2}{|c|}{$\mathrm{CD4}^{+}(\%)$} \\
\hline & & & & $\begin{array}{c}\text { Before } \\
\text { treatment }\end{array}$ & $\begin{array}{c}\text { After } \\
\text { treatment }\end{array}$ & $\begin{array}{c}\text { Before } \\
\text { treatment }\end{array}$ & $\begin{array}{c}\text { After } \\
\text { treatment }\end{array}$ & $\begin{array}{c}\text { Before } \\
\text { treatment }\end{array}$ & $\begin{array}{c}\text { After } \\
\text { treatment }\end{array}$ & $\begin{array}{c}\text { Before } \\
\text { treatment }\end{array}$ & $\begin{array}{c}\text { After } \\
\text { treatment }\end{array}$ \\
\hline $\begin{array}{l}\text { Control } \\
\text { group }\end{array}$ & 36 & $\begin{array}{c}31.12 \pm \\
1.26\end{array}$ & $\begin{array}{c}39.76 \pm \\
2.26\end{array}$ & $\begin{array}{c}25.72 \pm \\
1.24\end{array}$ & $\begin{array}{c}26.93 \pm \\
3.62^{\mathrm{a}}\end{array}$ & $\begin{array}{l}1.28 \pm \\
0.23\end{array}$ & $\begin{array}{l}1.48 \pm \\
0.12^{a}\end{array}$ & $\begin{array}{l}1.62 \pm \\
0.23\end{array}$ & $\begin{array}{l}1.81 \pm \\
0.26^{a}\end{array}$ & $\begin{array}{c}5.49 \pm \\
2.24\end{array}$ & $\begin{array}{l}9.36 \pm \\
2.26^{a}\end{array}$ \\
\hline $\mathrm{p}$ & & $p>0.05$ & $p<0.05$ & $p>0.05$ & $p<0.05$ & $p>0.05$ & $p<0.05$ & $p>0.05$ & $p<0.05$ & $p>0.05$ & $p<0.05$ \\
\hline
\end{tabular}

Note: Compared with before treatment, ${ }^{\mathrm{a}} \mathrm{p}<0.05$

TABLE 4: COMPARISON OF CYTOKINES BEFORE AND AFTER TREATMENT IN THE TWO GROUPS

\begin{tabular}{lccccccc}
\hline & & \multicolumn{2}{c}{ IL-6 } & \multicolumn{2}{c}{ IL-8 } & \multicolumn{2}{c}{ TNF-a } \\
\cline { 3 - 7 } Group & $\mathrm{n}$ & $\begin{array}{c}\text { Before } \\
\text { treatment }\end{array}$ & $\begin{array}{c}\text { After } \\
\text { treatment }\end{array}$ & $\begin{array}{c}\text { Before } \\
\text { treatment }\end{array}$ & $\begin{array}{c}\text { After } \\
\text { treatment }\end{array}$ & $\begin{array}{c}\text { Before } \\
\text { treatment }\end{array}$ & $\begin{array}{c}\text { After } \\
\text { treatment }\end{array}$ \\
\hline $\begin{array}{l}\text { Observation } \\
\text { group }\end{array}$ & 36 & $204.26 \pm 2.39$ & $100.28 \pm 2.31^{\mathrm{a}}$ & $136.72 \pm 14.30$ & $26.45 \pm 3.23^{\mathrm{a}}$ & $203.11 \pm 5.08$ & $116.22 \pm 5.23$ \\
Control group & 36 & $204.22 \pm 2.23$ & $105.12 \pm 1.23$ & $137.06 \pm 14.26$ & $31.82 \pm 3.21^{\mathrm{a}}$ & $202.22 \pm 5.88$ & $119.82 \pm 4.21^{\mathrm{a}}$ \\
$\mathrm{t}$ & & 0.086 & -12.946 & -0.118 & -8.255 & 0.802 & -3.753 \\
$\mathrm{p}$ & & $\mathrm{p}>0.05$ & $\mathrm{p}<0.05$ & $\mathrm{p}>0.05$ & $\mathrm{p}<0.05$ & $\mathrm{p}>0.05$ & $\mathrm{p}<0.05$ \\
\hline
\end{tabular}

Note: Compared with before treatment, ${ }^{\mathrm{a}} \mathrm{p}<0.05$

TABLE 5: COMPARISON OF ADVERSE EVENTS AFTER TREATMENT BETWEEN THE TWO GROUPS

\begin{tabular}{lcccccc}
\hline Group & $\mathrm{n}$ & Vomiting & Nausea & Diarrhea & Nephrotoxicity & $\begin{array}{c}\text { Adverse } \\
\text { reaction rate }\end{array}$ \\
\hline $\begin{array}{l}\text { Observation } \\
\text { Group }\end{array}$ & 36 & $2(5.56)$ & $2(5.56)$ & $1(5.56)$ & $0(0.00)$ & $5(11.12)$ \\
Control group & 36 & $1(2.78)$ & $1(2.78)$ & $2(5.56)$ & $0(0.00)$ & $4(13.90)$ \\
\hline
\end{tabular}


The main mechanism of antibacterial drugs is to achieve the purpose of sterilization by inhibiting bacterial protein synthesis or destroying bacterial cell wall and bacterial clearance rate is the main evaluation index ${ }^{[10]}$. This study indicated that bacterial clearance rate in the observation group was significantly higher than that in the control group. Considering that linezolid is a broad spectrum antimicrobial agent, it has both the powerful effect of first-generation cephalosporin against gram-positive coccus and the stability of thirdgeneration cephalosporin against broad spectrum Beta ( $\beta$ )-lactamase, so it can effectively inhibit gram negative bacilli ${ }^{[11,12]}$. In this study, MRSA accounted for $38.89 \%$ and linezolid can play an effective scavenging role. Therefore, after treatment with linezolid, its antibacterial efficiency is higher.

The occurrence and development of tuberculosis is closely related to the cellular and humoral immune functions of the body and the decline of immunity will cause pulmonary infection and further aggravate the disease ${ }^{[13]}$. In this study, $\mathrm{CD} 4^{+}, \mathrm{CD} 8^{+}, \mathrm{CD} 4^{+} / \mathrm{CD} 8^{+}$, IgA and IgG levels were significantly increased in the 2 groups after treatment and the improvement was more obvious in the patients treated with linazolid, suggesting a better recovery of immune function. Patients with pulmonary tuberculosis severe pneumonia, will cause fever, difficulty breathing, thus increasing the body's energy consumption, at the same time due to insufficient intake of calories, nutrition can cause patients lack of lower immunity ${ }^{[14]}$ and severe infection causes the body $\mathrm{T}$ lymphocyte and B lymphocyte apoptosis, increase the body's immune function decline. This resulted in reduced levels of $\mathrm{CD}^{+}, \mathrm{CD}^{+}, \mathrm{CD} 4^{+} / \mathrm{CD} 8^{+}, \mathrm{IgA}$ and IgG. In the observation group, the antibacterial effect was more effective, which could reduce the body's energy consumption and resist the development of inflammation, so as to better promote the recovery of the body's immune function. In a study ${ }^{[15]}, 46$ patients with tuberculosis were treated with linezolid and their immune function was significantly improved, which was consistent with the results of this study.

Cytokines play a role in inhibiting bacteria and protecting the body during the occurrence and development of inflammation and effectively regulate the body's immune function ${ }^{[16]}$. This study suggested that after treatment, the levels of IL-6, IL-8 and TNF- $\alpha$ in 2 groups were significantly decreased and the above indexes in the observation group were more significantly decreased, suggesting that the observation group had better infection control after treatment.
Studies have suggested that IL-6, IL- 8 and TNF- $\alpha$ can reflect the severity of inflammation and the more severe the inflammation, the higher the level of IL-6. IL-6 is produced by $\mathrm{CD}^{+} \mathrm{T}$ cells and macrophages, and its main function is to activate the activity of $\mathrm{T}$ cells, $\mathrm{B}$ cells and NK cells in the body, increase the immunity of the body and thus increase the ability of the body to resist bacteria. The main role of IL- 8 is to induce neutrophils to transport to the site of inflammatory reaction and play a guiding role, so that the body's epidemic prevention system can kill pathogens more effectively ${ }^{[17]}$. At the same time, IL- 8 can regulate the body's immune balance by presenting antigens to the body's immune system. The role of TNF- $\alpha$ is to produce granulation tissue in the body, which protects against further attacks by the Mycobacterium tuberculosis. However, when over secreted, TNF- $\alpha$ can damage lung structures and cause cavern tuberculosis. The increase of the above cytokines can protect the body and inhibit bacteria. Due to the higher bacterial clearance rate in the observation group, the above indexes decreased more and at the same time, it can effectively avoid the destruction of lung tissue structure caused by TNF- $\alpha$ over secretion. In terms of adverse reactions, there was no statistically significant difference between the two groups, indicating that combined treatment with linezolid was safe.

The occurrence and development of tuberculosis is closely related to the immune function of the body. After treatment, the immune function of the observation group was significantly higher than that of the control group and the bacterial clearance rate of the observation group was higher. Therefore, linezolid can effectively improve the prognosis of patients. The observation group had a better clinical outcome due to the high bacterial clearance rate of the treatment and better immunity enhancement.

In conclusion, the treatment of pulmonary tuberculosis complicated with severe pneumonia by lineczolid can improve the clinical efficacy, enhance immune function, reduce cytokines and improve the survival rate of patients, with guaranteed safety.

\section{Acknowledgements:}

This work was supported by The Second Hospital of Nanjing, Nanjing University of Chinese Medicine.

\section{Conflict of interests:}

The author reported that there is no conflict of interest. 


\section{REFERENCES}

1. Livermore DM, Warner M, Mushtaq S. Activity of MK7655 combined with imipenem against Enterobacteriaceae and Pseudomonas aeruginosa. J Antimicrob Chemother 2013;68(10):2286-90.

2. Hirsch EB, Ledesma KR, Chang KT, Schwartz MS, Motyl MR, Tam VH. In vitro activity of MK-7655, a novel $\beta$-lactamase inhibitor, in combination with imipenem against carbapenem-resistant Gram-negative bacteria. Antimicrob Agents Chemother 2012;56(7):3753-7.

3. Lob SH, Hackel MA, Kazmierczak KM, Hoban DJ, Young $\mathrm{K}$, Motyl MR, et al. In vitro activity of imipenem-relebactam against gram-negative bacilli isolated from patients with lower respiratory tract infections in the United States in 2015-Results from the Smart Global Surveillance Program. Diagn Microbiol Infect Dis 2017;88(2):171-6.

4. Lob SH, Hackel MA, Kazmierczak KM, Young K, Motyl MR, Karlowsky JA, et al. In vitro activity of imipenem-relebactam against gram-negative eskape pathogens isolated by clinical laboratories in the United States in 2015 (Results from the Smart Global Surveillance Program). Antimicrob Agents Chemother 2017;61(6):e02209-16.

5. Lucasti C, Vasile L, Sandesc D, Venskutonis D, McLeroth $\mathrm{P}$, Lala M, et al. Phase 2, dose-ranging study of relebactam with imipenem-cilastatin in subjects with complicated intra-abdominal infection. Antimicrob Agents Chemother 2016;60(10):6234-43.

6. Sharma R, Park TE, Moy S. Ceftazidime-avibactam: a novel cephalosporin/ $\beta$-lactamase inhibitor combination for the treatment of resistant gram-negative organisms. Clin Ther 2016;38(3):431-44.

7. Singer BH, Newstead MW, Zeng X, Cooke CL, Thompson $\mathrm{RC}$, Singer K, et al. Cecal ligation and puncture results in longterm central nervous system myeloid inflammation. PLoS One 2016;11(2):e0149136.

8. Rizk ML, Rhee EG, Jumes PA, Gotfried MH, Zhao T, Mangin $\mathrm{E}$, et al. Intrapulmonary pharmacokinetics of relebactam, a novel $\beta$-lactamase inhibitor, dosed in combination with imipenem-cilastatin in healthy subjects. Antimicrob Agents Chemother 2018;62(3):e01411-17.

9. Okamoto K, Gotoh N, Nishino T. Alterations of susceptibility of Pseudomonas aeruginosa by overproduction of multidrug efflux systems, MexAB-OprM, MexCD-OprJ and MexXY/ OprM to carbapenems: substrate specificities of the efflux systems. J Infect Chemother 2002;8(4):371-3.
10. Chinen Y, Nakamura S, Tamashiro K, Sakamoto O, Tashiro K, Inokuchi $\mathrm{T}$, et al. Isovaleric acidemia: Therapeutic response to supplementation with glycine, L-carnitine or both in combination and a 10-year follow-up case study. Mol Genet Metab Rep 2017;11:2-5.

11. Masuda N, Sakagawa E, Ohya S, Gotoh N, Tsujimoto H, Nishino T. Substrate specificities of MexAB-OprM, MexCDOprJ and MexXY-oprM efflux pumps in Pseudomonas aeruginosa. Antimicrob Agents Chemother 2000;44(12):33227.

12. Blizzard TA, Chen H, Kim S, Wu J, Bodner R, Gude C, et al. Discovery of MK-7655, a $\beta$-lactamase inhibitor for combination with Primaxin ${ }^{\circledR}$. Bioorg Med Chem Lett 2014;24(3):780-5.

13. Mukae H. 113th Scientific Meeting of the Japanese Society of Internal Medicine: Educational Lecture: Importance of Early Diagnosis and Treatment in Patients with Systemic Sclerosis. Nihon Naika Gakkai Zasshi 2016;105(9):1864-9.

14. Nakamura I, Nagakura T, Fujita H, Fukusima S, Gonoi T. Nocardia elegans infection: A case report and literature review. Int J Infect Dis 2017;54:15-7.

15. Lee JY, Kim DK, Lee JK, Yoon HI, Jeong I, Heo E, et al. Substitution of ethambutol with linezolid during the intensive phase of treatment of pulmonary tuberculosis: Study protocol for a prospective, multicenter, randomized, open-label, phase II trial. Trials 2017;18(1):1-8.

16. Rizk ML, Zou L, Savic RM, Dooley KE. Importance of drug pharmacokinetics at the site of action. Clin Transl Sci 2017;10(3):133-42.

17. Stein GE, Wells EM. The importance of tissue penetration in achieving successful antimicrobial treatment of nosocomial pneumonia and complicated skin and soft-tissue infections caused by methicillin-resistant Staphylococcus aureus: Vancomycin and linezolid. Current medical research and opinion 2010;26(3):571-88.

This is an open access article distributed under the terms of the Creative Commons Attribution-NonCommercial-ShareAlike 3.0 License, which allows others to remix, tweak, and build upon the work non-commercially, as long as the author is credited and the new creations are licensed under the identical terms

This article was originally published in a special issue, "Novel Therapeutic Approaches in Biomedicine and Pharmaceutical Sciences" Indian J Pharm Sci 2021:83(6) Spl Issue "84-89" 